\title{
SOME OBSERVATIONS ON THE DISTRIBUTION OF CHAETOGNATHA WEST OF PENANG ISLAND
}

$\operatorname{AUTHOR}(\mathrm{S})$ :

Pathansali, D.

\section{CITATION:}

Pathansali, D.. SOME OBSERVATIONS ON THE DISTRIBUTION OF CHAETOGNATHA WEST OF PENANG ISLAND. PUBLICATIONS OF THE SETO MARINE BIOLOGICAL LABORATORY 1968, 15(5): 391-397

\section{ISSUE DATE:}

1968-03-25

URL:

http://hdl.handle.net/2433/175481

RIGHT: 


\title{
SOME OBSERVATIONS ON THE DISTRIBUTION OF CHAETOGNATHA WEST OF PENANG ISLAND
}

\author{
D. PATHANSALI
}

Fisheries Research Institute, Penang

With 1 Text-figure

\section{Introduction}

This report is based on the collections of plankton made by the Fisheries Division's vessel, M.V. Kembong, once a month over a period of eight months, from July, 1963, to February, 1964, west of Penang Island. The collections were made at five pairs of stations with the first pair close to shore and the successive pairs situated some ten miles apart and extending seaward (Fig. I).

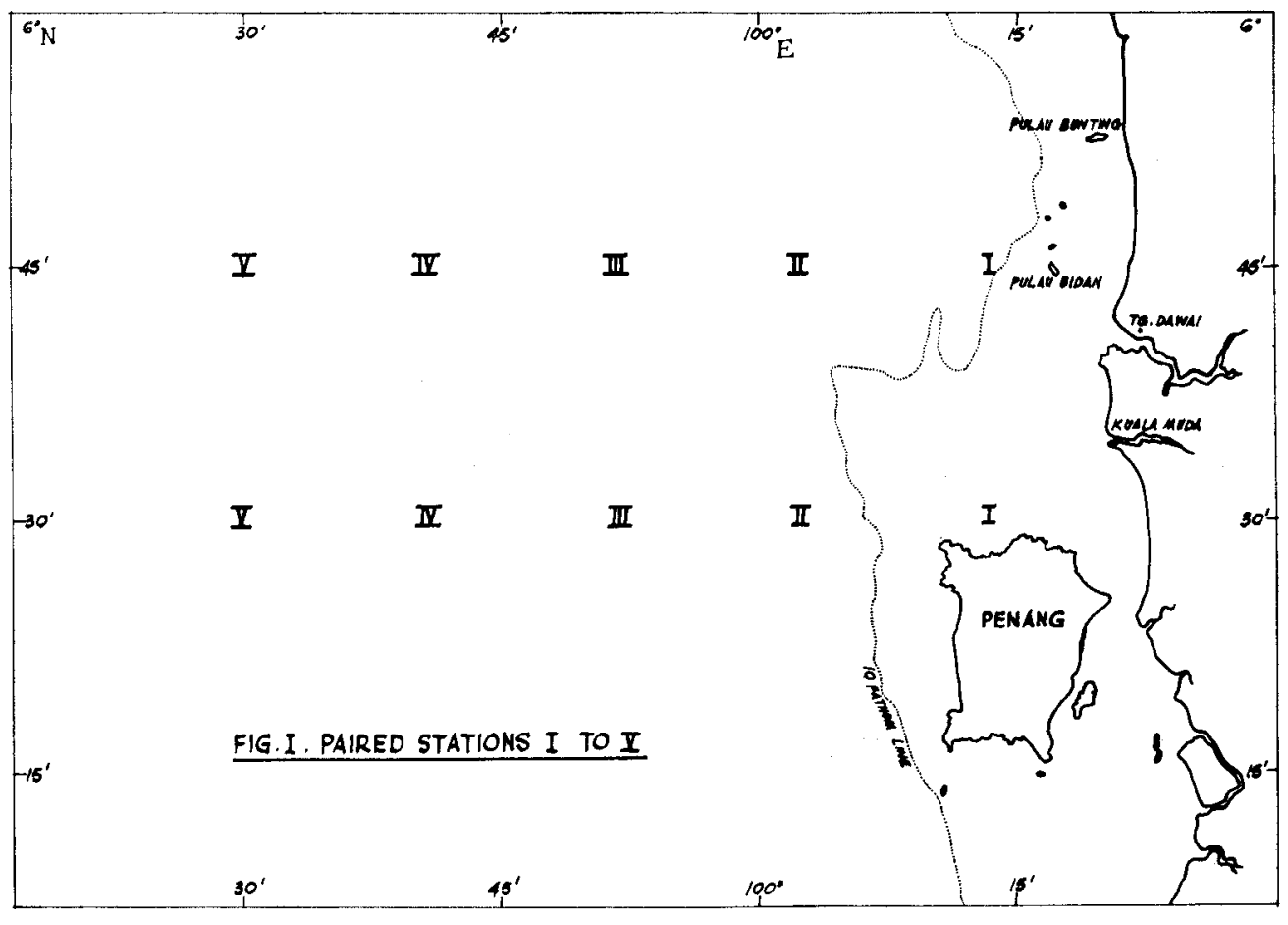

Publ. Seto Mar. Biol. Lab., XV (5), 391-397, 1968. (Article 25) 
The North Pacific Standard Net, with mesh of Japanese Standard GG 54 and fitted with a flow-meter for the quantitative estimation of the volume of water filtered, was used throughout for the collections. Two vertical hauls, from bottom to surface, were made at each station.

In the laboratory all the Chaetognatha were removed from each sample, separated according to species and their numbers per 100 cubic meters of water filtered estimated. Although the paired stations showed some differences in the numbers of a species present yet, as the trends in abundance and distribution were similar, the estimates for each species at each pair of stations were pooled to give an average value. The estimates were made for each species recorded at each pair of stations every month but in the final analysis only the average numbers of each species at each pair of stations over the period of eight months are given (Table 3 ).

\section{Observations}

Species composition: Altogether 17 species of four genera, including two forms, were recorded. They were:

Genus Sagitta Quoy and GaImarD

S. bedfordii Doncaster

S. bedoti BÉRANECK

$S$. bedoti $\mathrm{f}$. littoralis Tokioka et Pathansali

$S$. bedoti f. minor Tokioka

S. delicata TokiokA

$S$. demipenna Tokioka et Pathansali

S. enflata Grassi

S. ferox Doncaster

S. neglecta AIDA

S. oceanica GREY

S. pacifica ToKIoKa

S. pulchra Doncaster

S. regularis AIDA

S. robusta DONCASTER

Genus Krohnitta RitTer ZÁHony

K. pacifica (AIDA)

Genus Pterosagitta Costa

P. draco (KROHN)

Genus Spadella Langerhans

S. angulata TokiokA

Occurrence and distribution:

Table 1 summarises the number of species represented at each station from July, 1963, to February, 1964. Taking the mean values for the eight months Station I 
was the poorest in species, 6.7; the number of species increased quite rapidly to Station II, 9.6, and then more gradually to station III, 10.7, and to Stations IV and $\mathrm{V}, 11.4$.

Table 1. Number of species recorded at each station during each month and total number of species recorded during the eight months at each station.

\begin{tabular}{|c|c|c|c|c|c|}
\hline \multirow{2}{*}{ MONTH } & \multicolumn{5}{|c|}{ STATION } \\
\hline & I & II & III & IV & $\mathrm{V}$ \\
\hline July, 1963 & 8 & 11 & 13 & 12 & 12 \\
\hline August & 7 & 8 & 11 & 12 & 11 \\
\hline September & 7 & 8 & 10 & 11 & 13 \\
\hline October & 4 & 9 & 10 & 11 & 10 \\
\hline November & 7 & 12 & 12 & 12 & 12 \\
\hline December & 8 & 10 & 9 & 10 & 9 \\
\hline January, 1964 & 7 & 7 & 10 & 11 & 12 \\
\hline February & 6 & 12 & 11 & 12 & 12 \\
\hline Mean & 6.7 & 9.6 & 10.7 & 11.4 & 11.4 \\
\hline $\begin{array}{l}\text { Total number of } \\
\text { species recorded }\end{array}$ & 10 & 15 & 14 & 15 & 14 \\
\hline
\end{tabular}

When the total number of species that were recorded at each station are considered again Station I was the poorest with 10 species, while the other stations were about similar, with 14 or 15 species. This increase in species from shore to seaward may be attributed to the decrease in the fluctuations in salinity from shore, which is more affected by the discharge of rivers, to seaward, where the salinity is, comparatively, more stable. However, in terms of abundance the Chaetognatha were most abundant at Station I and declined in abundance seaward. This may be attributed to the greater productivity of the inshore waters, Doty et al (1962) and LonGHuRsT (1966).

The data of Table 2 summarise the occurrence of each species at each station during the eight months.

Of the 17 species ten were present throughout and the rest occurred sporadically at one or more stations. These two groups may be regrouped into five sub-groups which indicate, generally, the order of abundance of each species.

Sub-group I comprising $S$. enflata and $K$. pacifica was present throughout at all stations.

Sub-group II comprises $S$. bedfordii and $S$. oceanica which were respectively present throughout at four stations but absent once or more at the remaining station.

Sub-group III comprises $S$. bedoti f. minor and $S$. demipenna, which respectively occurred throughout at three stations, but absent once or more at the remaining two stations.

Sub-group IV comprises $S$. neglecta, S. bedoti, S. pulchra and S. robusta, which were 
Table 2. Number of times each species was recorded at each station during the eight months.

\begin{tabular}{|c|c|c|c|c|c|}
\hline \multirow{2}{*}{ SPECIES } & \multicolumn{5}{|c|}{ STATION } \\
\hline & I & II & III & IV & $\mathrm{V}$ \\
\hline S. enflata & 8 & 8 & 8 & 8 & 8 \\
\hline K. pacifica & 8 & 8 & 8 & 8 & 8 \\
\hline S. bedfordii & 6 & 8 & 8 & 8 & 8 \\
\hline S. oceanica & 8 & 8 & 8 & 8 & 7 \\
\hline S. bedoti f. minor & 1 & 7 & 8 & 8 & 8 \\
\hline S. demipenna & 6 & 8 & 8 & 8 & 7 \\
\hline S. bedoti & 8 & 7 & 4 & 1 & 0 \\
\hline S. neglecta & 1 & 7 & 7 & 7 & 8 \\
\hline S. pulchra & 0 & 4 & 8 & 6 & 7 \\
\hline S. robusta & 0 & 4 & 8 & 7 & 7 \\
\hline S. bedoti f. littoralis & 3 & 1 & 0 & 0 & 0 \\
\hline S. delicata & 5 & 0 & 0 & 0 & 0 \\
\hline S. ferox & 0 & 2 & 4 & 6 & 6 \\
\hline S. pacifica & 0 & 2 & 1 & 4 & 5 \\
\hline S. regularis & $\mathbf{0}$ & 1 & 4 & 6 & 6 \\
\hline P. draco & 0 & 2 & 2 & 5 & 5 \\
\hline Sp. angulata & 0 & 0 & 0 & 2 & 2 \\
\hline
\end{tabular}

respectively present throughout at only one station, but absent once or more at the remaining stations or absent throughout at one station in some species.

Sub-group V comprises the sporadically occurring species such as $S$. bedoti f. littoralis, $S$. delicata, $S$. ferox, $S$. pacifica, $S$. regularis, $P$. draco and $S p$. angulata

Abundance: Table 3 gives the mean numbers of respective species at each station for the eight months. It will be seen that respective species were more abundant at some particular station than at others and declined in abundance seaward, shoreward or both. The stations of the most abundant occurrence of respective species were:

Station I S. bedfordii, S. bedoti, S. bedoti f. littoralis, S. delicata, S. enflata, $S$. oceanica and $K$. pacifica.

Station II S. demipenna

Station III $\quad S$. bedoti f. minor, S. neglecta, $S$. pulchra and S. robusta.

Station IV $S$. ferox, $S$. regularis and $S p$. angulata

Station V P. pacifica and $P$. draco.

There is a trend, but not a clear cut one, from neritic to oceanic forms from shore to seaward stations. The overlap is due mainly to the forms widely distributed in the neritic and oceanic provinces. Inspite of this, it is possible to classify the 
Table 3. Average numbers per 100 cubic metres of each species at each station during the eight months.

\begin{tabular}{l|r|r|r|r|r}
\hline \multirow{2}{*}{ SPECIES } & \multicolumn{5}{|c}{ STATION } \\
\cline { 2 - 6 } & \multicolumn{1}{|c|}{ I } & II & III & IV & V \\
\hline S. bedfordii & 313.58 & 118.99 & 92.09 & 46.72 & 13.24 \\
S. bedoti & 215.58 & 47.34 & 3.29 & 0.18 & 0 \\
S. bedoti f. littoralis & 9.53 & 1.99 & 0 & 0 & 0 \\
S. bedoti f. minor & 4.27 & 53.25 & 99.45 & 59.06 & 38.58 \\
S. delicata & 75.96 & 0 & 0 & 0 & 0 \\
S. demipenna & 12.32 & 144.66 & 79.57 & 28.47 & 7.79 \\
S. enflata & 1249.63 & 724.66 & 505.93 & 305.04 & 252.76 \\
S. ferox & 0 & 4.23 & 8.11 & 11.20 & 2.78 \\
S. neglecta & 1.06 & 64.67 & 78.17 & 43.50 & 35.59 \\
S. oceanica & 256.49 & 74.52 & 29.83 & 27.86 & 10.51 \\
S. pacifica & 0 & 0.46 & 0.26 & 2.21 & 6.29 \\
S. pulchra & 0 & 2.87 & 7.65 & 2.93 & 2.38 \\
S. regularis & 0 & 1.23 & 5.75 & 10.17 & 10.08 \\
S. robusta & 0 & 6.06 & 15.03 & 14.58 & 9.47 \\
K. pacifica & 553.29 & 179.57 & 58.27 & 39.33 & 32.01 \\
S. draco & 0 & 0.46 & 1.16 & 4.06 & 5.11 \\
Sp. ang:lata & 0 & 0 & 0 & 0.48 & 0.37 \\
\hline
\end{tabular}

species as neritic, nertic-oceanic, oceanic-neritic and oceanic forms. The neritic forms may be divided into neritic-inshore and neritic-offshore forms. To the first group belong $S$. bedoti f. littoralis and $S$. delicata. Their outermost seaward limit appears to be around Stations I and II. They are species essentially inhabiting the lower saline waters. S. bedoti could also, perhaps, be classified under this group. The neritic-offshore forms are $S$. bedfordii, $S$. demipenna and $S$. oceanica. The neriticoceanic forms, more widely distributed in the neritic than in the oceanic province are $S$. bedoti f. minor, $S$. enflata, $S$. neglecta and $K$. pacifica. The oceanic-neritic forms are $S$. pulchra, S. robusta, $S$. ferox and $S$. regularis, $S$. pacifica and $P$. draco form the last group, the oceanic forms.

In these groupings the more important and useful forms which could perhaps be used to identify the water characteristics are those classified as neritic-inshore and oceanic. The former indicates the presence and seaward extent of low salinity inshore water while the latter indicates the presence and the extent of the incursion of oceanic water. The species in the neritic-offshore and in the oceanic-neritic groups could, perhaps, be used to identify neritic and mixed, neritic-oceanic, waters respectively. The rest are, however, too widely distributed and without well defined limit to be considered useful as indicators.

Salinity and temperature: The range of salinity and temperature from surface to bottom, at 20 metre intervals, during the eight months are given in Table 4 . The 
surface salinity and temperature were, except at Station I, alike from Stations II to $\mathrm{V}$, but below the surface, with increasing distance from shore and with increasing depth, the trends were an increase in salinity and a decrease in temperature. Though there was not a remarkable increase in the salinity of the bottom water particularly at Stations III to V during the latter months of the investigations there was a significant decrease in temperature from December to February with the lowest temperatures being recorded in February.

Table 4. Range of salinity and temperasures at each depth for each station during the eight months.

\begin{tabular}{|c|c|c|c|c|c|c|}
\hline & & \multicolumn{5}{|c|}{ STATION } \\
\hline & & I & II & III & IV & V \\
\hline \multirow[t]{2}{*}{ Surface } & $\mathrm{S} \%$ & $29.58-31.80$ & $30.50-31.60$ & $30.80-31.80$ & $30.60-31.80$ & $30.80-31.80$ \\
\hline & $\mathrm{T}^{\circ} \mathrm{C}$ & $28.15-29.89$ & $29.10-29.80$ & $29.28-29.95$ & 29.06-30.27 & $28.86-30.06$ \\
\hline \multirow[t]{2}{*}{20 Meters } & $\mathrm{S} \%$ & $31.72-32.40$ & $32.60-32.90$ & $32.23-33.00$ & $32.10-33.40$ & $32.00-33.40$ \\
\hline & $\mathrm{T}^{\circ} \mathrm{C}$ & $27.75-28.53$ & $26.89-29.24$ & $26.55-29.41$ & $26.08-28.87$ & $25.98-28.80$ \\
\hline \multirow[t]{2}{*}{40 Meters } & $\mathrm{S} \%$ & & & $33.10-33.60$ & $32.90-33.80$ & $32.60-33.90$ \\
\hline & $\mathrm{T}^{\circ} \mathrm{C}$ & & & $25.90-27.97$ & $24.85-28.11$ & $24.10-28.48$ \\
\hline \multirow{2}{*}{60 Meters } & $\mathrm{S} \%$ & & & & $33.10-33.60$ & $33.40-34.00$ \\
\hline & $\mathrm{T}^{\circ} \mathrm{C}$ & & & & $24.88-26.37$ & $22.95-25.72$ \\
\hline
\end{tabular}

\section{Conclusions}

This investigation shows that the species in the two groups, neritic-inshore and oceanic, which display a segregation in distribution, are sporadic in occurrence and fewer in number, could be useful as indicators of the water characteristics. To the neritic-inshore forms, $S$. bedoti f. littoralis and $S$. delicata may be added to more species, $S$. bombayensis LeLe et GAE and $S$. johorensis Pathansal. et Tokioka recorded eleswhere along the west coast of the Malay Peninsula. These two species inhabit the inshore waters of low salinity.

The oceanic forms, $S$. pacifica and $P$. draco are of particular interest, for they indicate the presence of oceanic water. According to Ommaney (1961) and Wrakstead (1961) there is an incursion of oceanic water from the Andaman Sea southwards along the bottom through the Straits of Malacca. WraKsTEAD considers, from hydrographical and planktological data, that the limit of this incursion to be approximately along a line from $4^{\circ} \mathrm{N}, 99^{\circ} \mathrm{E}$ to $3^{\circ} \mathrm{N}, 100^{\circ} \mathrm{E}$. OMmaNey citing SoeriaAtmadja (1956) states that this incursion of oceanic water reaches the One Fathom Bank where it rises and flows with the surface current which, it is generally agreed, flows northwards through the Straits of Malacca throughout the year.

From the limited investigations made on the distribution of the Chaetognatha south of Penang Island (unpublished data) it would appear that both S. pacifica and 
$P$. draco do not occur south of a line drawn westwards of Penang Island. If the southward limit of the distribution of these two species is taken to indicate the presence of the oceanic water, then the observations made here are in agreement with that of WigksTEAD's conclusion on the extent of the incursion of the oceanic water southwards through the northern part of the Straits of Malacca. However, the absence of these two species south of Penang Island may be attributed to the gradual loss of the characteristics of the oceanic water through mixing as it moves southward through the Straits of Malacca. South of Penang Island the oceanic-neritic forms, S. pulchra, $S$. robusta, $S$. ferox and $S$. regularis, generally considered as oceanic forms, are present but in lesser numbers.

Salinity and temperature records show an increase in salinity and decrease in temperature of the bottom water during the latter months of this investigation particularly at the offshore stations. Whilst these indicate an incursion of the oceanic water, they also show that the incursion is not of equal strength throughout the year.

\section{Acknowledgement}

I wish to express my gratitude to Mr. Soong Mrv Kong, Director of Fisheries, Malaysia, for his encouragement and keen interest in the study of the Chaetognatha.

\section{REFERENCES}

Alvariño, A. (1965): Chaetognaths. Oceanogr. Mar. Biol. Ann. Rev., Vol. 3, pp. 115-194.

Doty, M.S., R.E. SoeriaAtmadja and A. Soegiarta (1962): Observations on the primary productivity of Northwestern Indonesian waters. Marine Research in Indonesia, No. 5.

Longhurst, A.R. (1966): Biological basis of tropical fisheries. 2nd. International Oceanographic Congress, Moscow: Abstract of papers, No. 262.

Ommaney, F.D. (1961): Malayan offshore trawling grounds. Fish. Publ. London, No. 18.

RAo, T.S.S. (1958a): Studies on Chaetognatha in the Indian Seas. Part 2: The Chaetognatha of the Lawson's Bay, Waltair. Andhra Univ. Mem. Oceanogr., Ser. 62, Vol. 2, pp. 137-146.

- and P.N. Ganapati (1958): Studies on Chaetognatha in the Indian Seas. Part 3: Systematics and distribution in the waters off Visakhapatam. Andhra Univ. Mem. Oceanogr., Ser. 62, Vol. 2, pp. 147-163.

RAO, T.S.S. (1958b): Studies on Chactognatha in the Indian Seas, Part 4: Distribution in relation to currents. Andhra Univ. Mem. Oceanogr., Ser. 62, Vol. 2, pp. 164-167.

Soeriadtmadja, Rd. E., (1956): Surface salinities in the Straits of Malacca. Marine Research in Indonesia, No. 2.

Tокіока, T. (1938): A new Chaetognatha (Sagitta crassa n. sp) from Ise Bay. Zool. Mag., Japan, Vol. 50, No. 6, pp. 349-351.

pp. $129-139$.

(1939): Three new chaetognaths from Japanese waters. Mem. Mar. Obs. Kobe, Vol. 7, (1940): The chaetognath fauna of the waters of western Japan. Rec. Oceanogr. Wks. Japan, Vol. 12, pp. 1-22.

(1952): Chaetognaths of the Indo-Pacific. Annot. Zool. Japon., Vol. 25, Nos. 1-2, pp. $307-316$.

(1965): Supplementary notes on the systematics of Chaetognatha. Publ. Seto Mar. Biol. Lab., Vol. 13, No. 3, pp. 231-242.

Wickstead, J.H. (1961): A quantitative and qualitative study of some Indo-West-Pacific plankton. Fish. Publ. London, No. 16. 